\title{
АКТУАЛЬНОСТЬ РАЗРАБОТКИ И ПРИМЕНЕНИЯ ЭКОЛОГИЧЕСКОГО ПАСПОРТА ДЛЯ ОБЩЕСТВЕННЫХ ЗДАНИЙ И СООРУЖЕНИЙ
}

\section{Светлана Александровна Бондарева}

Сибирский государственный университет геосистем и технологий, 630108, Россия, г. Новосибирск, ул. Плахотного, 10, обучающийся, тел. (960)793-95-30, e-mail: lodochka1997@mail.ru

\section{Евгения Ивановна Баранова}

Сибирский государственный университет геосистем и технологий, 630108, Россия, г. Новосибирск, ул. Плахотного, 10, кандидат технических наук, доцент кафедры экологии и природопользования, тел. (913)922-07-72 e-mail: evg.dxn@yandex.ru

В статье обосновывается актуальность разработки и применения экологического паспорта для таких объектов недвижимости как общественные здания и сооружения, так как при осуществлении своей деятельности данные объекты недвижимости не только используют природные ресурсы, но и оказывают негативное влияние на состояние окружающей среды. Рассмотрены цели разработки экопаспорта для общественных зданий и сооружений и его значимость в настоящее время. Предложена структура разработанного экологического паспорта, которая может быть индивидуальной для каждого конкретного объекта. Экологический паспорт, разработанный для общественных зданий и сооружений, состоит из шести разделов, включающих в себя основные сведения об объекте, а также экологопроизводственные показатели. Рассмотрена практическая значимость экологического паспорта для общественных зданий и сооружений.

Ключевые слова: природопользователи, объекты недвижимости, общественные здания и сооружения, состояние окружающей среды, природные среды, негативное воздействие, экологический паспорт, экологический контроль

\section{RELEVANCE OF THE DEVELOPMENT AND APPLICATION OF AN ECOLOGICAL PASSPORT FOR PUBLIC BUILDINGS AND FACILITIES}

\section{Svetlana A. Bondareva}

Siberian State University of Geosistems and Technologies, 10, Plakhotnogo St., Novosibirsk, 630108, Russia, Student, phone: (960)793-95-30, e-mail: lodochka1997@mail.ru

\section{Evgenyia I. Baranova}

Siberian State University of Geosistems and Technologies, 10, Plakhotnogo St., Novosibirsk, 630108, Russia, Ph. D., Associate Professor, Department of Ecology and Environmental Management, phone: (913)922-07-72 e-mail: evg.dxn@yandex.ru

The article substantiates the relevance of the development and application of an ecological passport for such real estate objects as public buildings and structures, since the implementation of their activities they do not only use natural resources, but also have a negative impact on the environment. The goals of developing an ecological passport for public buildings and structures and its significance are regarded. The structure of the developed ecological passport, which can be individual for each specific object, is proposed. The developed ecological passport for public buildings and structures consists of six sections, which include basic information about the facility, as well as environmental and production indicators. The practical significance of the ecological passport for public buildings and structures is considered. 
Keywords: users of natural resources, real estate objects, public buildings and structures, state of the environment, natural environments, negative impact, ecological passport, ecological control

В настоящее время развитие и рост городов, а также других крупных населенных пунктов, обуславливается увеличением территорий, в большинстве своем, занятых под земли промышленности и земли поселений. В связи с чем естественные природные среды нарушаются путем антропогенного воздействия, которое приводит к нарушению динамического равновесия природных систем. Все это результат нерационального природопользования [1].

Однако, негативное воздействие на природные среды оказывают не только промышленные предприятия, но и другие объекты, например, общественные здания и сооружения, которые также являются природопользователями, так как в результате своей деятельности непосредственно используют природные ресурсы и оказывают воздействие на состояние окружающей среды.

Общественные здания и сооружения - это объекты недвижимости, в которых протекают процессы жизнедеятельности людей. Такие объекты представляют собой ограниченное строительными конструкциями пространство, предназначенное для кратковременного или длительного пребывания людей, а также защиты от внешних воздействий природных и антропогенных факторов. К ним относятся: торговые центры, образовательные учреждения, административные здания и офисы, спортивные комплексы, вокзалы и многое другое [2].

В таких объектах недвижимости как общественные здания и сооружения, как правило, сосредотачивается большое количество людей. Поэтому также важно учитывать факторы внешней среды, которые могут негативно сказываться на состоянии их здоровья. Это может зависеть от расположения такого объекта относительно автомобильных дорог, находящихся вблизи промышленных предприятий, полигонов и т.п.

Если рассматривать общественные здания и сооружения как объектыприродопользователи, то можно установить, что в результате своей деятельности они, как и другие природопользователи, используют такие ресурсы как: электроэнергия, вода, земля, на которой расположено здание или сооружение. И также оказывают незначительное, но все же негативное воздействие на состояние окружающей среды путем образования твердых коммунальных отходов (ТКО), коммунальных сбросов, выбросов загрязняющих веществ в атмосферу в случаях, если объекты имеют отдельные котельные [3].

Природоохранная деятельность занимает важное место в государственном управлении и регулировании экономики. Поэтому для стабилизации и улучшения состояния окружающей природной среды необходимым является создание системы экологической паспортизации объектов природопользователей, являющихся источниками загрязнения окружающей природной среды. Экологический паспорт (экопаспорт) - это документ, который содержит информацию об использовании природных ресурсов природопользователем, степени его воздействия на окружающую среду, а также рекомендациях для минимизации такого воздействия [4]. 
В настоящее время экологический паспорт разработан и применим для таких природопользователей, как промышленные предприятия. Однако и он, согласно письму Министерства природных ресурсов России (МПР) от 06.09.2001 г. № 33-01-8/3047 «Об экологическом паспорте», носит рекомендательный характер, то есть необязателен и разрабатывается по желанию руководителя предприятия. Также, согласно ГОСТ Р 17.0.0.06-2000 «Охрана природы. Экологический паспорт. Типовые формы», экологический паспорт не может отменять или заменять другие нормативные документы в области природоохранной деятельности [5-7].

С точки зрения экологического контроля общественные здания и сооружения также как промышленные объекты могут учитываться и оцениваться по степени их влияния на состояние окружающей среды. Поэтому необходима разработка такого экологического паспорта, который будет учитывать сведения, относящиеся непосредственно к таким объектам недвижимости [8].

Для этого необходимо форматирование существующих разделов действующего экологического паспорта для природопользователей. Экологический паспорт для общественных зданий и сооружений может иметь индивидуальную структуру, подходящую непосредственно исследуемому объекту.

В процессе разработки экологического паспорта за основу были взяты типовые формы из ГОСТ Р 17.0.0.06-2000 «Охрана природы. Экологический паспорт. Типовые формы», однако они были изменены и добавлены новые, которые будут учитывать сведения непосредственно объекта исследования.

Для общественного здания или сооружения, разработанный экологический паспорт может состоять из шести разделов, включающих в себя типовые формы для внесения в них данных:

- титульный лист;

- сведения о разработчике экопаспорта, включающие в себя наименование, адрес и наличие лицензий на разработку экопаспорта;

- общие сведения об общественном здании или сооружении, указывающие его наименование, местонахождение, классификационные признаки и т.д.;

- сведения о потреблении энергии, в которых приведена характеристика топливно-энергетических ресурсов;

- эколого-производственные показатели, включающие в себя:

а) сведения по использованию природных ресурсов: количество источников выбросов, количество и качественную характеристику выбрасываемых загрязняющих веществ, наличие газоочистных установок, данные о водопотреблении, характеристику бытовых отходов, сведения по их образованию, движению и размещению;

б) сведения о влиянии антропогенных источников загрязнения, где содержится информация об антропогенных загрязнениях, оказывающих влияние на исследуемую территорию;

в) сведения о планируемых природоохранных мероприятиях, включающие план мероприятий по улучшению состояния окружающей среды исследуемой территории [9-16]. 
Разработанный экологический паспорт для общественных зданий и сооружений будет учитывать два аспекта. Первый заключается в том, какую негативную нагрузку оказывает объект исследования на состояние окружающей среды, а второй будет указывать на источники загрязнения, которые оказывают негативное воздействие на людей, находящихся продолжительное время в таком здании или сооружении $[17,18]$.

Практическая значимость разработки и применения экологического паспорта для общественных зданий и сооружений заключается в учете всех объектов природопользователей, оказывающих негативное воздействие на природные среды какой-либо территории, а также в более доступном получении сведений об этих объектах при заполнении экологической отчетности, в целях осуществления государственного экологического мониторинга $[19,20]$.

\section{БИБЛИОГРАФИЧЕСКИЙ СПИСОК}

1. Степанько Н.Г. Рациональное природопользование и экологическая устойчивость территории // Вестник Томского государственного универчитета. - 2017. - С. 173-176.

2. СП 118.13330.2012*. Свод правил. Общественные здания и сооружения. Актуализированная редакция СНиП 31-06-2009 [Электронный ресурс]. - Режим доступа: http://docs.cntd.ru/document/1200092705.

3. Федеральный закон «Об охране окружающей среды» № 7-Ф3 от 10.01.2002 г. [Электронный ресурс]. - Режим доступа: http://www.consultant.ru/document/cons_doc_LAW_34823.

4. Куклева Н.Н. Экологический паспорт природопользователя: учебное пособие. - ТД "Учитель-Канц", 2019. - 32с.

5. Письмо Министерства природных ресурсов России (МПР) от 06.09.2001 г. № 33-01$8 / 3047$ «Об экологическом паспорте» [Электронный ресурс]. - Режим доступа: http://wiki.integral.ru/index.php/06.09.2001-_письмо_МПР_России_N_33-01-8/3047.

6. ГОСТ Р 17.0.0.06-2000 «Охрана природы. Экологический паспорт природопользователя. Основные положения. Типовые формы.» [Электронный ресурс]. - Режим доступа: http://www.consultant.ru/cons/cgi/online.cgi?req=doc\&base=EXP\&n=434444.

7. Постановление Госстандарта РФ от 11.09.2000 г. № 218-ст. «О принятии и введении в действие государственного стандарта» [Электронный ресурс]. Режим доступа: http://www.consultant.ru/document/cons_doc_LAW_256767.

8. Снытко В. А., Собисевич А. В. Система экологического мониторинга в научном наследии академиков И. П. Герасимова и Ю. А. Израэля // Труды пятой международной научно-практической конференции "Индикация состояния окружающей среды: теория, практика, образование", 30 ноября - 3 декабря 2017 года: сборник статей. М., 2017. С. 393-398.

9. ГОСТ Р 51379-99. «Энергосбережение. Энергетический паспорт промышленного потребителя топливно-энергетических ресурсов. Основные положения. Типовые формы» [Электронный ресурс]. - Режим доступа: http://docs.cntd.ru/document/1200005377.

10. ГОСТ 17.2.1.03-84 «Охрана природы (ССОП). Атмосфера. Термины и определения контроля загрязнения〉 [Электронный ресурс]. - Режим доступа: http://docs.cntd.ru/document/1200009365.

11. ГОСТ 17.1.1.01-77 «Охрана природы (ССОП). Гидросфера. Использование и охрана вод. Основные термины и определения〉 [Электронный ресурс]. - Режим доступа: http://docs.cntd.ru/document/1200009357.

12. Федеральный закон «Об отходах производства и потребления» № 89-Ф3 $\begin{array}{lllll}\text { от 24.06.1998 [Электронный } & \text { ресурс]. }\end{array}$ http://www.consultant.ru/document/cons_doc_LAW_19109. 
13. Об утверждении Федерального классификационного каталога отходов № 242 от 22.05.2017 года [Электронный ресурс]. http://docs.cntd.ru/document/542600531.

14. СанПиН 42-128-4690-88 от 05.08.1988 г. «Санитарные правила содержания территорий населенных мест» [Электронный ресурс]. - Режим доступа: http://docs.cntd.ru.

15. СанПиН 2.2.1/2.1.1.1200-03 «Санитарно-защитные зоны и санитарная классификация предприятий, сооружений и иных объектов» от 25.09.2007 года № 74 [Электронный ресурс]. - Режим доступа: http://www.consultant.ru/document/cons_doc_LAW_74669.

16. Об утверждении Правил установления санитарно-защитных зон и использования земельных участков, расположенных в границах санитарно-защитных зон от 03.03.2018 № 222 [Электронный pecypc]. - 2 Режим доступа: http://www.consultant.ru/document/cons_doc_LAW_292487.

17. Федеральный закон «О внесении изменений в Федеральный закон «Об охране окружающей среды» и отдельные законодательные акты Российской Федерации» № 404-Ф3 от 29.12.2015 года [Электронный ресурс]. - Режим доступа: http://www.consultant.ru/document/cons_doc_LAW_191291/3d0cac60971a511280cbba229d9b632 9c07731f7/\#dst100010.

18. Бондарева, С. А., Баранова Е. И. Разработка экологического паспорта общественных зданий и сооружений на примере среднего общеобразовательного учреждения // Интерэкспо ГЕО-Сибирь. XVI Междунар. науч. конгр., 22-24 апреля 2020г., Новосибирск : сб. материалов в 9 т. Т. 6 : Магистерская научная сессия «Первые шаги в науке». [Электронный ресурс]. - Новосибирск : СГУГиТ, 2020. No1. - С. 42-47. Режим доступа: http://geosib.sgugit.ru/magisterskaya-nauchnaya-sessiya-pervye-shagi-v-nauke-tom6-1-2020.

19. Постановление Правительства РФ «Об утверждении критериев определения объектов, подлежащих федеральному государственному экологическому надзору» № 903 от $\begin{array}{lllll}\text { 28.08.2015 года } \text { [Электронный } & - & \text { Режим доступа: }\end{array}$ http://www.consultant.ru/document/cons_doc_LAW_185330.

20. Муртазов А. К. Экологический мониторинг. Методы и средства: Учебное пособие. Часть 1 / А. К. Муртазов; Рязанский государственный университет им. С. А. Есенина. — Рязань, 2018. - 146 с.

(C) С. А. Бондарева, Е. И. Баранова, 2021 